\title{
Breast Safety Progress through Exercise-Driven Lactation: A Pragmatic Bioprocess to Prevent Cancer
}

\section{Akbar Nikkhah*}

Chief Highly Distinguished Professor, Department of Animal Sciences, University of Zanjan, Iran

The objective of this article was to describe a novel bioprocess to help prevent cancer through augmenting lactation, especially driven by adequate physical activity. The methodology of this biotechnique is based on the philosophy that increased exercise improves appetite and nutrient turnover in favour of milk biosynthesis in mammary glands, thereby decreasing the likelihood of fat deposition where milk must be produced and fat depots must not be developed. Mammary adiposity and reduced lactation capacity predispose breast cells to oncogenesis.

Maintaining regularities in cell biology is becoming more difficulty as modernity overwhelmingly steps into human lifestyle. Such an altered cell physiology has led to increased risks for obesity, metabolic syndrome and various types of cancer [1-3]. Despite the greater average longevity, the increased modern human age has not necessarily been admired by more comfortable and higher quality life $[4,5]$. Breast cancer as a leading cause of mortality and morbidity in women is increasingly under extensive medical care and research [6]. However, the modern human society requires rather feasible approaches that prevent cancer incidence and not impose significant costs of treatment and care $[7,8]$.

By definition, physical activity helps establish regularities in cellular substrate uptake and oxidation and postpones aging via improved waste management [8]. Since parturition is physiologically followed by anorexia and hypophagia, many women are prone to cancer development via different sets of incompletely known mechanisms. This endocrinological trend represses lactation, facilitates adiposity, and predisposes mammary cells to future oncogenesis. Intensive, regular and durable physical activity can considerably enhance demands for energy and complementary nutrients and capacitate the mammary cells for a persistent lactation [3,7]. However, prolonged effective nutrition and consistent exercise programs must be co-maintained to allow the cells to utilize the nutrients towards milk biosynthesis. Such an exercise-driven endocrinology and food intake behaviour (e.g., multiple times daily) helps keep the breast cells away from creating hazardous irregularities in biochemical and gene-oriented cycles.

To pragmatically conclude, increased regularities in intensive and durable exercise (i.e., those activities that cause sweating and multiplied heart work) will smoothly lead breast cells towards development of innovative regularities in cell physiology that could ultimately reduce cancer risk. More research is a must to delineate the mechanisms linking intensive exercise and breast cancer incidence.

\section{Acknowledgments}

Gratefully thanked are the Iran's Ministry of Science Research and Technology, National Elite Foundation, and University of Zanjan for supporting the author's global programs of optimizing science edification policies in the third millennium.

\section{References}

1. Nikkhah A (2013) NutriGenomics: An Epi-Innovative Science (Book In Persian), Jahade-Daneshgahi Publishing Organization, Zanjan-Tehran, Iran.

2. Nikkhah A (2012) Science of eating time: A novel chronophysiological approach to optimize glucose-insulin dynamics and health. J Diabetes Mellit 2: 8.

3. United States Report of Department of Health and Human Services (1996) Physical activity and health: a report of the Surgeon General. US Department of Health and Human Services, Centers for Disease Control and Prevention. National Center for Chronic Disease Prevention and Health Promotion.

4. Shephard RJ (1997) Aging, physical activity, and health. Human Kinetics Publishers, USA, 488.

5. Nikkhah A (2014) Aging evolution: A postmodern public apprehension. Int $J$ Med Pharm 2: 1-22.

6. Jemal A, Siegel R, Ward E, Hao Y, Xu J, et al. (2009) Cancer statistics. CA Cancer J Clin 59: 225-249.

7. Nikkhah A (2015) Wrecked oncogenesis through synchronized substrate availability and oxidation: A novel bioengineering of cell physiology. Aust $J$ Biotechnol Bioeng

8. Nikkhah A (2015) Establishing rhythmic regularities in cell physiology: A nove global program to thwart cancer. J Nutr Health Food Eng.
*Corresponding author: Akbar Nikkhah, Chief Highly Distinguished Professor, Department of Animal Sciences, Faculty of Agricultural Sciences, University of Zanjan, Zanjan, Iran, National Elite Foundation, Tehran, Iran, Tel: +98-24-350328-01; Fax: +98-24-350-332-02; E-mail: nikkhah@znu.ac.ir

Received February 27, 2015; Accepted February 28, 2015; Published March 03, 2015

Citation: Nikkhah A (2015) Optimizing Gestation and Early Life Physiology through Timing of Energy Turnover: Bioprocessing of Human Life. J Bioprocess Biotech 5: e127 doi:10.4172/2155-9821.1000e127

Copyright: (c) 2015 Nikkhah A. This is an open-access article distributed unde the terms of the Creative Commons Attribution License, which permits unrestricted use, distribution, and reproduction in any medium, provided the original author and source are credited. 